\title{
How Can We Make Decision for Patients With Chronic Hepatitis B According to Hepatitis B Virus (HBV) DNA Level?
}

\author{
Maryam Keshvari ${ }^{1,2}$; Seyed Moayed Alavian ${ }^{2,3,} ;$ Heidar Sharaf $^{2,3}$ \\ ${ }^{1}$ Blood Transfusion Research Center, High Institute for Research and Education in Transfusion Medicine, Tehran, IR Iran \\ ${ }^{2}$ Middle East Liver Disease (MELD) Center, Tehran, IR Iran \\ 3 Baqiyatallah Research Center for Gastroenterology and Liver Diseases, Baqiyatallah University of Medical Sciences, Tehran, IR Iran \\ ${ }^{*}$ Corresponding Author: Seyed Moayed Alavian, Baqiyatallah Research Center for Gastroenterology and Liver Diseases, Baqiyatallah University of Medical Sciences, Mollasadra St., \\ Vanak Sq., Tehran, IR Iran. Tel:+98-2188945186, Fax:+98-2188945188, E-mail: editor@hepatmon.com
}

Received: October 7, 2013; Revised: October 19, 2013; Accepted: October 25, 2013

\begin{abstract}
Background: HBeAg negative hepatitis B infection exerts both inactive carrier state and chronic active hepatitis, which are sometimes difficult to differentiate. Serial hepatitis B virus (HBV) DNA quantification, alanine transaminase (ALT) measurement, and liver histology assessment can help to differentiate these forms of hepatitis B infection.

Objectives: We aimed to clarify the clinical and laboratory characteristics of HBeAg negative hepatitis B patients.

Patients and Methods: Patients with hepatitis B, referred to Tehran Blood Transfusion Hepatitis Clinic from 2011 to 2013, were included and followed for one year. Laboratory assessments including liver function tests, HBVDNA quantification, and liver biopsy (for some cases) were performed.

Results: Two hundred forty-three HBeAg negative hepatitis B patients were stratified into three groups based on to their HBV DNA level including group 1(G1) with HBV DNA level < $2000 \mathrm{IU} / \mathrm{mL}$, group 2 (G2) with HBV DNA level 2000-20000 IU/mL, and group 3 (G3) with HBV DNA level > $20000 \mathrm{IU} / \mathrm{mL}$. The G2 had more similarity to G1 than G3 regarding their clinical characteristics.

Conclusions: It is concluded that most HBeAg negative hepatitis B patients with serum HBV DNA level of 2000-20000 IU/mL, persistent normal ALT concentration, and no or mild liver damage on biopsy can be clinically managed as HBV inactive carriers.
\end{abstract}

Keywords: Hepatitis B; Liver Cirrhosis; Viral Load

\section{Background}

Hepatitis B virus (HBV) infection is a significant health problem. Approximately 350 million persons worldwide are chronically infected with HBV. Patients with chronic HBV infection are at increasing risk of end stage liver disease such as cirrhosis and hepatocellular carcinoma (HCC). According to different studies, 15\% to $40 \%$ of $\mathrm{HBV}$ infected patients develop serious complications of hepatitis $B(1,2)$. The prevalence of HBV infection in Iran was estimated to be $2.14 \%$ (3). All HBV isolates from Iran were genotype $\mathrm{D}(4,5)$. The rate of precore and basal core promoter mutations and progressive liver disease in patients with HBV genotype D infection was found to be more prevalent than HBV infected patients with non-D genotypes $(6,7)$. Hepatitis B infection consists of few clinical phases including immune tolerance phase, immune clearance phase, and inactive carrier state. Inactive carrier state is characterized by normal alanine transaminase (ALT) concentration, absence of HBeAg and presence of anti-HBeAb, low or undetectable HBV DNA in serum, and minimal or no histologic changes on liver biopsy. Some patients continue to have moderate levels of HBV replication and active liver disease, but remain to have negative results for $\mathrm{HBeAg}$ which most of them have the HBV variants that cannot produce HBeAg due to mutations in the basal core promoter or precore regions (8). According to the last guideline for management of hepatitis $\mathrm{B}$, absence of HBeAg, presence of anti-HBeAb, Serum HBV DNA level $<2000 \mathrm{IU} / \mathrm{mL}$, persistent normal ALT/aspartate transaminase (AST) level, and absence of significant hepatitis on liver biopsy are classified as inactive carrier state. Whereas, $\mathrm{HBeAg}$ positivity or serum HBV DNA level > $20000 \mathrm{IU} /$ $\mathrm{mL}$, persistent or intermittent elevation in ALT/AST level, and liver biopsy showing chronic hepatitis with moderate to severe necro-inflammation are classified as chronic active hepatitis B (9). This classification is important since antiviral therapy must be considered just for the patients with chronic active hepatitis presentation. However, differentiation between HBeAg negative chronic active hepatitis B and inactive carrier state is often challenging. We have observed some patients with HBV infection in

Implication for health policy/practice/research/medical education:

$2000 \mathrm{IU} / \mathrm{mL}$ or $20000 \mathrm{IU} / \mathrm{mL}$, it is the question. While Baseline HBV viral load is one of the main determinants for classification of patients with HBV infection into different forms of disease, there is still disagreement regarding the cutoff value for such application of HBV viral load. In this study, we searched for the appropriate cutoff value and application of HBV viral load to differentiate HBeAg negative chronic active hepatitis B patients from HBV inactive carriers based on their clinical and laboratory assessments.

Copyright (c) 2014, BRCGL; Published by Kowsar Corp. This is an open-access article distributed under the terms of the Creative Commons Attribution License, which permits unrestricted use, distribution, and reproduction in any medium, provided the original work is properly cited. 
the clinic with normal ALT levels, and HBV DNA levels between $2000 \mathrm{IU} / \mathrm{mL}$ and $20000 \mathrm{IU} / \mathrm{mL}$ and no or minimal fibrosis on their liver biopsy. Classification of this group of HBV infected patients into chronic active hepatitis or inactive carrier state is a great question.

\section{Objectives}

The aim of this study was to precise assessment of HBeAg negative hepatitis B infected patients according to their clinical and laboratory features.

\section{Patients and Methods}

In the current study, a total of 243 treatment naive HBV infected patients referred to Tehran Blood Transfusion Hepatitis Clinic (Tehran, Iran) from 2011 to 2013 were included and followed for one year. HBeAg positive chronic hepatitis B patients and cases with human immunodeficiency and hepatitis $\mathrm{C}$ and D antibodies were excluded. Laboratory assessments including liver function tests and HBV DNA quantification (HBV DNA level) were performed for the study population on at least two consecutive patients' samples in a one-year interval. Upper normal limit of ALT was considered 34 IU/L for nonoverweight women (BMI of less than 25), and $40 \mathrm{IU} / \mathrm{L}$ for non-overweight men (10). HBV DNA level using COBAS TaqMan HBV tests (Roche Diagnostics) and liver biopsy (The results were reported according to the modified Knodell scoring system, as the Ishak score.) was assessed.
On liver histology, liver fibrosis score (stage) $\leq 2$, and liver necro-inflammation score (grade) $\leq 4$ were considered as cutoff values to show mild liver damage (11). The liver histology assessment was performed for patients with clinical and laboratory evidence of progressive liver disease, while it was performed optionally for those without such evidence. All study participants provided informed consent, and the study design was approved by appropriate ethics review board. Statistical analysis was performed using SPSS version 20. Categorical variables and continuous variables were analyzed by Fisher exact test and t-test, respectively. P values less than 0.05 were considered to be statistically significant.

\section{Results}

In the current study, $243 \mathrm{HBeAg}$ negative hepatitis B patients were divided into three groups regarding their HBV DNA level including group1 (G1) with HBV DNA level $<2000 \mathrm{IU} / \mathrm{mL}$, group2 (G2) with HBV DNA level between $2000 \mathrm{IU} / \mathrm{mL}$ to $20000 \mathrm{IU} / \mathrm{mL}$, and group3 (G3) with HBV DNA level > $20000 \mathrm{IU} / \mathrm{mL}$. We observed that G2 had more similarity to G1 than G3 (Table 1). There was no statistically significant difference regarding sex, necro-inflammatory score on liver biopsy (grade), and total bilirubin concentration between these groups $(\mathrm{P}>0.05)$, but there were significant differences in liver fibrosis (stage), AST, ALT and direct bilirubin mean concentrations between G2 and G3 $(\mathrm{P}<0.05)$ (Table 1$)$.

Table 1. Comparison of Demographic and Clinical Characteristics of the Study Population Stratified by HBV DNA

\begin{tabular}{|c|c|c|c|c|c|}
\hline & $\begin{array}{l}\text { HBV DNA }<2000 \mathrm{IU} / \\
\mathrm{mL}(\mathrm{G} 1)(\mathbf{n}=104)\end{array}$ & $\begin{array}{l}\text { HBV DNA } 2000-20000 \\
\text { IU } / \mathrm{mL}(\mathrm{G} 2)(\mathbf{n}=53)\end{array}$ & $\begin{array}{l}\text { HBV DNA > } 20000 \\
\mathrm{IU} / \mathrm{mL}(\mathrm{G} 3)(\mathbf{n}=\mathbf{8 6})\end{array}$ & $\begin{array}{l}\text { Pvalue G1 } \\
\text { vs. G2 }\end{array}$ & $\begin{array}{l}\text { P value G2 } \\
\text { vs. G3 }\end{array}$ \\
\hline Age, Mean $\pm S D, y$ & $47.4 \pm 12.7$ & $41.8 \pm 12.8$ & $43.5 \pm 13.9$ & $0.01^{\mathrm{a}}$ & $0.46^{\mathrm{a}}$ \\
\hline \multicolumn{6}{|l|}{ Sex, No. (\%) } \\
\hline Female & $19(18.3)$ & $16(30.2)$ & $22(25.6)$ & $0.11^{\mathrm{b}}$ & $0.56^{b}$ \\
\hline Male & $85(81.7)$ & $37(69.8)$ & $64(74.4)$ & & \\
\hline \multicolumn{6}{|l|}{ Liver Fibrosis, No. (\%) } \\
\hline Mild & $16(94.1)$ & $29(87.9)$ & $41(56.2)$ & $0.65^{b}$ & $<0.01^{\mathrm{b}}$ \\
\hline Moderate to severe & $1(5.9)$ & $4(12.1)$ & $32(43.8)$ & & \\
\hline \multicolumn{6}{|l|}{$\begin{array}{l}\text { Liver Necro-Inflammation, } \\
\text { No. (\%) }\end{array}$} \\
\hline Mild & $12(80.0)$ & $14(48.3)$ & $30(42.3)$ & $0.06^{\mathrm{b}}$ & $0.66^{\mathrm{b}}$ \\
\hline Moderate to severe & $3(20.0)$ & $15(51.7)$ & $41(57.7)$ & & \\
\hline $\operatorname{ALT}^{\mathrm{C}}, \operatorname{Mean} \pm \mathrm{SD}, \mathrm{IU} / \mathrm{L}$ & $40.3 \pm 28.7$ & $40.5 \pm 27.0$ & $68.5 \pm 53.1$ & $0.98^{\mathrm{a}}$ & $<0.01^{\mathrm{a}}$ \\
\hline $\operatorname{AST}^{\mathrm{C}}$, Mean $\pm \mathrm{SD}, \mathrm{IU} / \mathrm{L}$ & $29.7 \pm 17.1$ & $32.1 \pm 18.6$ & $46.9 \pm 26.5$ & $0.42^{\mathrm{a}}$ & $<0.01^{\mathrm{a}}$ \\
\hline $\begin{array}{l}\text { Direct bilirubin, Mean } \pm S D \text {, } \\
\text { mg/dL }\end{array}$ & $0.23 \pm 0.14$ & $0.31 \pm 0.19$ & $0.42 \pm 0.39$ & $<0.01^{\mathrm{a}}$ & $0.03^{\mathrm{a}}$ \\
\hline $\begin{array}{l}\text { Total bilirubin, Mean } \pm S D \text {, } \\
\text { mg/dL }\end{array}$ & $0.92 \pm 0.54$ & $1.08 \pm 0.58$ & $1.24 \pm 0.89$ & $0.10^{\mathrm{a}}$ & $0.26^{\mathrm{a}}$ \\
\hline
\end{tabular}


Keshvari M et al.

\section{Discussion}

A previous study showed that HBV DNA level more than $20000 \mathrm{IU} / \mathrm{mL}$ can be considered as a cutoff value to differentiate patients with HBeAg negative chronic active hepatitis B and those in an inactive carrier state (12). However, another study proposed that due to the fluctuation in HBV DNA level among HBeAg negative chronic hepatitis $B$ patients, there is no absolute cutoff value reliable to differentiate HBeAg negative chronic active hepatitis B patients and hepatitis B inactive carriers (13). Another study confirmed that ALT $\leq 30 \mathrm{IU} / \mathrm{L}$ and HBVDNA load $\leq$ $20000 \mathrm{IU} / \mathrm{mL}$ had high sensitivity, specificity, positive predictive value (PPV), and negative predictive value (NPV) to differentiate HBV inactive carriers and HBeAg negative chronic active hepatitis B (14). In a cohort of Alaska natives, among HBeAg negative hepatitis B patients, 25\% met the criteria for chronic active HBV infection. The patients had mild histologic liver changes, if HBV DNA level never exceed $20000 \mathrm{IU} / \mathrm{mL}$ during the follow up period (15). A study from Greece showed that histologically significant liver disease was rare in patients with $\mathrm{HBV}$ infection with persistent normal liver enzymes, and HBV DNA $\leq 20000$ $\mathrm{IU} / \mathrm{mL}$, so these patients could be considered as true inactive HBV carriers (16). On the other hand, in different studies, HBV DNA level of $2000 \mathrm{IU} / \mathrm{mL}$ was considered to differentiate inactive carriers and $\mathrm{HBeAg}$ negative chronic hepatitis B $(17,18)$. However HBV DNA level can fluctuate to lower than $2000 \mathrm{IU} / \mathrm{mL}$ in patients with HBeAg negative chronic hepatitis $\mathrm{B}$, and as a result $\mathrm{HBV}$ clinical state can be misclassified based on a single HBV DNA level, so appropriate follow-up by HBV DNA and ALT levels is recommended to differentiate inactive carriers and patients with HBeAg negative chronic hepatitis B (18). One of our study limitations was its proportionally small number of patients with HBV DNA level $2000 \mathrm{IU} / \mathrm{mL}$ to $20000 \mathrm{IU} / \mathrm{mL}$. We propose a longitudinal study with larger sample size to seek the outcome of this group of patients.

In conclusion, it seems that patients with HBV infection should be followed regularly with ALT and HBV DNA levels assessment. The current study, demonstrated that most HBeAg negative hepatitis B patients with serum HBV DNA level between $2000 \mathrm{IU} / \mathrm{mL}$ to $20000 \mathrm{IU} / \mathrm{mL}$, persistent normal ALT concentration, and no or mild liver damage on biopsy could be considered as HBV inactive carriers.

\section{Acknowledgements}

We are grateful to the staff of Hepatitis Clinic of Tehran Blood Transfusion Center, and the Middle East Liver Disease (MELD) Center.

\section{Authors' Contribution}

All authors equally contributed in the study design, data collection, and manuscript preparation.

\section{Financial Disclosure}

Authors declared no financial disclosure regarding this study.

\section{Funding/Support}

This study had no funding source.

\section{References}

1. Lok AS, McMahon BJ. Chronic hepatitis B. Hepatology. 2007;45(2):507-39.

2. Aspinall EJ, Hawkins G, Fraser A, Hutchinson SJ, Goldberg D. Hepatitis B prevention, diagnosis, treatment and care: a review. Occup Med (Lond). 2011;61(8):531-40.

3. Alavian SM, Hajarizadeh B, Ahmadzad-Asl M, Kabir A, BagheriLankarani K. Hepatitis B Virus infection in Iran: A systematic review. Hepat Mon. 2008;8(4):281-94

4. Eftekhari Y, Kazemi Arababadi M, Hakimi H, Rezazadeh Zarandi E. Common HBV genotype in southeastern Iranian patients. Arch Iranian Med. 2010;13(2):147-9.

5. Garmiri P, Rezvan H, Abolghasemi H, Allain JP. Full genome characterization of hepatitis $B$ virus strains from blood donors in Iran. J Med Virol. 2011;83(6):948-52.

6. Malmstrom S, Eilard A, Larsson SB, Hannoun C, Norkrans G, Lindh M. Genotype impact on long-term virological outcome of chronic hepatitis B virus infection. J Clin Virol. 2012;54(4):321-6.

7. Shi YH. Correlation between hepatitis B virus genotypes and clinical outcomes. Jpn J Infect Dis. 2012;65(6):476-82.

8. McMahon BJ. Epidemiology and natural history of hepatitis B. Semin Liver Dis. 2005;25 Suppl 1:3-8.

9. Lok AS, McMahon BJ. Chronic hepatitis B: update 2009. Hepatology. 2009;50(3):661-2

10. Mohamadnejad M, Pourshams A, Malekzadeh R, Mohamadkhan A, Rajabiani A, Asgari AA, et al. Healthy ranges of serum alanine aminotransferase levels in Iranian blood donors. World J Gastroenterol. 2003;9(10):2322-4.

11. Fateen AA, Shahin RY, Farres MN, Eldeeb MA, Amer HA. Assessment of hepatic fibrosis and necroinflammation among inactive HBsAg carriers in Egypt. Ann Hepatol. 2012;11(4):464-70.

12. Chu CJ, Hussain M, Lok AS. Quantitative serum HBV DNA levels during different stages of chronic hepatitis B infection. Hepatology. 2002;36(6):1408-15.

13. Martinot-Peignoux M, Boyer N, Colombat M, Akremi R, Pham $\mathrm{BN}$, Ollivier S, et al. Serum hepatitis B virus DNA levels and liver histology in inactive HBsAg carriers. J Hepatol. 2002;36(4):543-6.

14. Ijaz B, Ahmad W, Javed FT, Gull S, Hassan S. Revised cutoff values of ALT and HBV DNA level can better differentiate HBeAg (-) chronic inactive HBV patients from active carriers. Virol J. 2011:8:86.

15. McMahon BJ, Bulkow L, Simons B, Zhang Y, Negus S, Homan C, et al. Relationship Between Level of HBV DNA and Liver Disease - a Population-Based Study of Hepatitits B e Antigen-Negative Persons with Hepatitis B. Clin Gastroenterol Hepatol. 2013.

16. Papatheodoridis GV, Manolakopoulos S, Liaw YF, Lok A. Follow-up and indications for liver biopsy in HBeAg-negative chronic hepatitis B virus infection with persistently normal ALT: a systematic review. J Hepatol. 2012;57(1):196-202.

17. Zacharakis G, Koskinas J, Kotsiou S, Tzara F, Vafeiadis N, Papoutselis M, et al. The role of serial measurement of serum HBV DNA levels in patients with chronic $\operatorname{HBeAg}(-)$ hepatitis B infection: association with liver disease progression. A prospective cohort study. J Hepatol. 2008;49(6):884-91.

18. Sorrell MF, Belongia EA, Costa J, Gareen IF, Grem JL, Inadomi JM, et al. National Institutes of Health consensus development conference statement: management of hepatitis B. Hepatology. 2009;49(5 Suppl):S4-S12. 